\title{
Potential drug-drug interactions in HIV-infected children on antiretroviral therapy in Lagos, Nigeria
}

\author{
This article was published in the following Dove Press journal: \\ HIVIAIDS - Research and Palliative Care \\ 5 April 2014 \\ Number of times this article has been viewed
}

\begin{abstract}
Kazeem A Oshikoya'
Ibrahim A Oreagba ${ }^{2}$

Saheed Lawal ${ }^{2}$

Olufunsho Awodele ${ }^{2}$

Olayinka O Ogunleye'

Idowu O Senbanjo 3

Sunday O Olayemi ${ }^{2}$

Veronica C Ezeaka ${ }^{4,5}$

Edamisan $\bigcirc$ Temiye $\mathrm{e}^{4,5}$

Titilope A Adeyemo ${ }^{4,6}$

Oluranti Opanuga ${ }^{4,7}$

Olufunmilayo A Lesi ${ }^{4,8}$

Sulaimon A Akanmu ${ }^{4,6}$

'Department of Pharmacology, Lagos State University College of Medicine, Ikeja, Lagos, Nigeria; ${ }^{2}$ Department of Pharmacology, College of Medicine, University of Lagos, Idi-Araba, Lagos, Nigeria; ${ }^{3}$ Department of Paediatrics, Lagos State University College of

Medicine, Ikeja, Lagos, Nigeria; ${ }^{4}$ APIN Clinic, Lagos University Teaching Hospital, Lagos, Nigeria; ${ }^{5}$ Department of Paediatrics, College of Medicine, University of Lagos, Idi-Araba, Lagos, Nigeria; 'Department of Haematology and Blood Transfusion, College of Medicine, University of Lagos, IdiAraba, Lagos, Nigeria; ${ }^{7}$ Department of Pharmacy, Lagos University Teaching Hospital, Idi-Araba Lagos, Nigeria; ${ }^{8}$ Department of Medicine, College of Medicine, University of Lagos, IdiAraba, Lagos, Nigeria
\end{abstract}

Correspondence: Kazeem Oshikoya Department of Pharmacology, Faculty of Basic Medical Sciences, Lagos State University College of Medicine, PMB 21 266, Ikeja, Lagos, Nigeria Tel +234802658 II I7 Email kazeemoshikoya@ymail.com
Background: Multi-therapy is common in HIV-infected children, and the risk for clinically significant drug interactions (CSDIs) is high. We investigated the prevalence of CSDIs between antiretroviral (ARV) and co-prescribed drugs for children attending a large HIV clinic in Lagos, Nigeria.

Methods: The case files of pediatric patients receiving treatment at the HIV clinic of the Lagos University Teaching Hospital (LUTH), Idi-Araba, between January 2005 and December 2010 were reviewed. The ARV and co-prescribed drug pairs were evaluated for potential interactions using the Liverpool HIV Pharmacology Group website. The potential interactions were rated as $\mathrm{A}$ (no known interaction), B (minor/no action needed), C (moderate/monitor therapy), D (major/therapy modification), and X (contraindicated/avoid combination).

Results: Of the 310 cases reviewed, 208 (67.1\%) patients were at risk of CSDIs. Artemisinin-based combination therapy was prescribed for over one-half of the patients, accounting for $40 \%$ of the CSDIs. Excluding this drug class, the prevalence of CSDIs reduced from $67.1 \%$ to $18.7 \%$ in 58 patients. Most of the CSDIs (579; 97.2\%) were moderately significant and frequently involved nevirapine and fluconazole $(58 ; 9.7 \%)$, zidovudine and fluconazole $(55 ; 9.2 \%)$, zidovudine and rifampicin $(35 ; 5.9 \%)$, and nevirapine and prednisolone $(31 ; 5.2 \%)$. Age $(P=0.392)$, sex $(P=0.783)$, and moderate $(P=0.632)$ or severe $(P=0.755)$ malnutrition were not associated with risk for CSDIs.

Conclusion: There is a tendency for CSDIs between ARV and co-prescribed drugs among the group of children evaluated in this study. Measures are necessary to prevent important drug interactions and to manage those that are unavoidable.

Keywords: infection, antiretroviral drug, co-prescribed drug, prevalence, therapy monitoring, therapy modification, contraindication

\section{Introduction}

Highly active antiretroviral (ARV) therapy (ART), defined as the combination of three or more ARV agents taken concurrently to suppress HIV replication, represents the current standard of care of ART for children infected with HIV. ${ }^{1}$ This strategy evolved from the recognition that treatment of chronic HIV infection with only one or two ARV agents typically results in rapid treatment failure and the development of ARV resistance, compromising future therapeutic options. ${ }^{1,2}$ In addition to the ART regimens, other medicines are typically required to manage numerous concurrent infections and systemic consequences of HIV/AIDS. Therefore, the likelihood of drug-drug interactions is increased in HIV-infected children on ART.

Theoretically, drug-drug interaction is defined as a phenomenon of two or more medicines interacting in such a manner that the effectiveness or toxicity of one or more drugs is altered. ${ }^{3}$ An interaction is said to be clinically significant 
if it requires a dosage adjustment of the culprit drugs or therapy monitoring or consists of a drug combination that is contraindicated due to its high potential for clinical adverse effects. ${ }^{4}$ Most of the previous studies that evaluated clinically significant drug interactions (CSDIs) were based on the use of electronic resources, databases, and/or reference books to assess the interactions and to determine if they were significant or not; ${ }^{4-8}$ however, in practice, only few cases of clinically significant interactions between coadministered medicines and ARV drugs have been reported..$^{9-12}$ This suggests that CSDIs may be less common than non-CSDIs in practice.

Case reports of CSDIs between ARV and coadministered drugs are lacking in children; however, such reports in adults have been documented in the literature. Bruce and Altice ${ }^{9}$ reported three cases of clinically significant pharmacokinetic interaction between opioid partial agonist (buprenorphine) and protease inhibitors ([PIs] atazanavir or atazanavir/ritonavir) that resulted in cognitive dysfunction of the patients. Atazanavir, alone or in combination with ritonavir, is known to be associated with substantial increase in buprenorphine exposure and delayed clearance. ${ }^{10}$ Similarly, clinical pharmacokinetic interactions between nevirapine (NVP) and methadone that resulted in opiate withdrawal syndrome have been reported. ${ }^{11}$ Efavirenz (EFV) is a potent inhibitor of CYP2C8 enzyme in vitro and may, therefore, potentially increase the plasma levels of amodiaquine when coadministered; ${ }^{12}$ however, the interaction is not expected to affect the therapeutic efficacy of the antimalarial, as both amodiaquine and its metabolite, N-desethylamodiaquine, are active antimalarials, but it may have implications for toxicity. German et $\mathrm{al}^{12}$ reported a case of 1.5-3-fold increase in the area under the plasma concentration curve for amodiaquine when coadministered with EFV and artesunate to two HIV-infected patients. The interaction between the drugs also resulted in asymptomatic but significant elevations in hepatic transaminases. Uriel and Lewthwaite ${ }^{13}$ also reported a case of an HIV-infected patient on abacavir (ABC), lamivudine (3TC), and NVP who also had Plasmodium falciparum malaria. The patient failed to respond to quinine treatment, which led the authors to suspect an interaction between NVP and quinine. Following a switch from quinine to atovaquone/proguanil (Malarone ${ }^{\circledR}$ ), the patient responded to the new antimalarial therapy and was subsequently discharged home after 48 hours.

Treatment may be compromised in children infected with both HIV and tuberculosis due to a significant interaction between lopinavir/ritonavir (LPV/r) or NVP and rifampicin; however, these interactions are documented only in theory, ${ }^{14,15}$ suggesting that they may be rare in clinical practice.

A good understanding of the mechanisms of drug interactions is essential to minimize or prevent adverse events and to prevent inadequate treatment. Interactions during drug absorption, distribution, hepatic metabolism, or renal excretion, resulting in an increased or a decreased plasma concentration and consequent altering of the pharmacological effects, are termed "pharmacokinetic interactions." The synergistic or antagonistic effects of two or more coadministered drugs, occurring at their sites of action, are termed "pharmacodynamic interactions."

All the PIs and non-nucleoside reverse transcriptase inhibitors (non-NRTIs) recommended by the World Health Organization (WHO) for HIV treatment in sub-Saharan African countries are metabolized in the cytochrome P450 system, principally by the CYP3A4 isoenzyme. The tendency for these groups of drugs to induce or inhibit CYP3A4 enzyme may lead to a decrease or increase in the serum levels of CYP3A4 substrates. ${ }^{16}$ Therefore, preventing and managing drug-drug interactions become major challenges in the optimization of HIV therapy. ${ }^{17,18}$

CSDIs are common, and a prevalence of $20 \%-41 \%$ has been reported in developed countries; ${ }^{4,8,18-21}$ however, there is a paucity of data from developing countries. A recent study by Kigen et $\mathrm{al}^{8}$ reported a risk of $33.5 \%$ for a potential CSDI with a tendency to lower ARV drug concentrations in $12 \%$ of adult HIV patients. HIV-infected African children often present late with acute opportunistic infections and other AIDS-associated conditions. ${ }^{22}$ These often require multiple therapies involving other medications that may increase the potential of the ARV drugs for CSDIs.

To our knowledge, there are no studies concerning drugdrug interactions in HIV-infected children on ARV drugs; such data would be of particular importance for African populations. We therefore investigated the frequency of potential drug-drug interactions in the prescriptions for HIVinfected children enrolled in ART at a teaching hospital in Lagos, Southwest Nigeria.

\section{Materials and methods Study design}

We retrospectively analyzed the clinical records of HIV-infected children who were receiving treatment at the AIDS Prevention Initiative in Nigeria (APIN) clinic, Lagos University Teaching Hospital (LUTH) in Nigeria, between January 2005 and December 2010. The APIN clinic is one of the United States Presidential Emergency Plan for AIDS Relief-funded centers 
for HIV relief program. The clinic is run every Monday to Friday, between 8 am and 4 pm.

On average, about 350 old and new patients (adults and children) are attended to daily at the APIN clinic. A total of 18 doctors, comprising four consultants, eight residents, and an average of six house officers, attend to the HIV-infected children during their visits to the APIN clinic. ARV drugs prescribed to the patients on ART enrollment are dispensed at the pharmacy free of charge. Patients were seen usually at the outpatient clinic every 4 weeks after commencing ART, and those on concomitant treatment for malaria, opportunistic infections, and comorbid conditions or manifesting adverse drug effects were initially followed up weekly, then biweekly, and, later, every 4 weeks.

All the HIV-infected children, including those who had progressed to full-blown AIDS, according to WHO criteria, ${ }^{1}$ and those who met the inclusion criteria, were included in the study. The inclusion criteria included children less than 16 years old who had been initiated on ART. Patients must have used ARV drugs at least once after enrollment and have had complete data documented in their records.

\section{Data abstraction}

Eligible cases were identified through the main register, obtained from the medical record of the APIN clinic. A coresearcher (SL) reviewed each case file and, using a standard form purposely designed for the study, extracted data on sex; weight; height; mode of contracting HIV; comorbid diseases and concomitant infections at presentation and follow-up; co-prescribed drugs; and the ARV drug regimen prescribed for each patient. Data extracted were double-checked by the lead researcher (KAO), a pediatric clinical pharmacologist, and another senior researcher (IAO).

The nutritional status of each patient was determined from the WHO child growth standards based on length or height, weight, and age. ${ }^{23}$ The nutritional status was classified as normal ( +3 standard deviation $[\mathrm{SD}] \leq Z \leq-1 \mathrm{SD}$ ), moderate malnutrition ( $-1 \mathrm{SD} \leq Z \leq-2 \mathrm{SD})$, or severe malnutrition $(Z \geq-3 \mathrm{SD})$.

\section{Prescribed ART regimen}

The national guidelines for HIV treatment in Nigeria recommend, as first-line ARV drugs for children, zidovudine (AZT) and 3 TC plus NVP or EFV, with substitution with stavudine or ABC allowed for toxicity. ${ }^{24}$ Second-line ARV drugs include any of the first-line drugs, didanosine (ddI) and $\mathrm{ABC}$ or ddI and AZT or ddI and EFV/NVP in combination with the PIs $\mathrm{LPV} / \mathrm{r}$ or saquinavir/ritonavir.

\section{Identification of potential interactions between co-prescribed and ARV drugs}

All co-prescribed and ARV drug pairs were screened for potential interactions using the Liverpool HIV Pharmacology Group website. ${ }^{25}$ This website comprises a comprehensive database of over 5,000 drug-interaction pairs and uses a "traffic light" system to flag potential interactions. In order to avoid overestimation of the CSDIs, all interactions flagged as red or amber were further scrutinized, and the quality of evidence underpinning these recommendations was assessed using criteria derived from the Grading of Recommendations, Assessment, Development, and Evaluation (GRADE) system (http://www.hiv-druginteractions.org/documents/QualityOfEvidence.pdf). ${ }^{26} \mathrm{CSDIs}$ were defined as those considered to be contraindicated or not recommended without close monitoring, or those requiring a dose adjustment to avoid side effects. ${ }^{4}$

\section{Classification of potential interactions between co-prescribed and ARV drugs}

The severity of interactions (CSDIs and non-CSDIs) was rated from $A$ to $D$ and $X$ (Table 1), according to the method of Armahizer et al $(\mathrm{A}=$ no known interaction; $\mathrm{B}=$ minor/ no action needed; $\mathrm{C}=$ moderate/monitor therapy; $\mathrm{D}=$ major/therapy modification; $\mathrm{X}=$ contraindicated/avoid

Table I Severity rating of the interactions between antiretroviral drugs and co-prescribed drugs

\begin{tabular}{|c|c|c|c|}
\hline Rating $^{\mathbf{a}}$ & Designation & Action & Explanation \\
\hline \multicolumn{4}{|c|}{ Clinically significant drug interaction } \\
\hline$x$ & Contraindicated & $\begin{array}{l}\text { Avoid } \\
\text { combination }\end{array}$ & $\begin{array}{l}\text { The drugs are contraindicated } \\
\text { for concurrent use. }\end{array}$ \\
\hline $\mathrm{D}$ & Major & $\begin{array}{l}\text { Consider } \\
\text { therapy } \\
\text { modification }\end{array}$ & $\begin{array}{l}\text { The interaction may be life } \\
\text { threatening and/or require } \\
\text { medical intervention to } \\
\text { minimize or prevent serious } \\
\text { adverse events. }\end{array}$ \\
\hline C & Moderate & $\begin{array}{l}\text { Monitor } \\
\text { therapy }\end{array}$ & $\begin{array}{l}\text { The interaction may result in } \\
\text { exacerbation of the patient's } \\
\text { condition and/or require an } \\
\text { alteration in therapy. }\end{array}$ \\
\hline \multicolumn{4}{|c|}{ Non-clinically significant drug interaction } \\
\hline B & Minor & $\begin{array}{l}\text { No action } \\
\text { needed }\end{array}$ & $\begin{array}{l}\text { The interaction would have } \\
\text { limited clinical effects. May } \\
\text { include an increase in the } \\
\text { frequency or severity of the } \\
\text { side effects but generally } \\
\text { would not require a major } \\
\text { alteration in therapy. }\end{array}$ \\
\hline$A$ & Unknown & $\begin{array}{l}\text { No known } \\
\text { interaction }\end{array}$ & Unknown. \\
\hline
\end{tabular}

Notes: ${ }^{\mathrm{a}} \mathrm{A}=$ no known interaction; $\mathrm{B}=$ minor/no action needed $\mathrm{C}=$ moderate/monitor therapy; $\mathrm{D}=$ major/therapy modification; $\mathrm{X}=$ contraindicated/avoid combination. ${ }^{27}$ 
combination). ${ }^{27}$ Interactions relating solely to overlapping toxicities, or between co-prescribed ARV drugs such as PI boosting, or involving dermal applications, were excluded. In addition, we excluded from our analysis potential interactions between 3TC and co-trimoxazole due to limited clinical significance suggested by controlled data. ${ }^{8}$

\section{Ethical issues}

The study protocol was approved by the research and ethics committee of LUTH. At the point of enrollment on ART, written consent was given by the parents, next of kin, caretakers, or guardians on the behalf of the minors/children for their information to be stored in the hospital database and used for research.

\section{Statistical analyses}

All data from the medical records were coded and results presented as median and range, mean $\pm \mathrm{SD}$, and frequency distribution with percentage. Patients were grouped according to whether they had a potential drug interaction versus no interaction.

The prevalence of CSDIs across individual NRTIs, non-NRTIs, and PIs were compared by chi-squared test at a significance level of 5\%. Multivariate logistic regression was performed with the age, sex, and nutritional status as covariates using the Statistical Package for the Social Sciences ([SPSS] v 16; IBM Corporation, Armonk, NY, USA).

\section{Results}

\section{Demographics of the patients}

A total of 337 patients were enrolled for ART but only 310 $(74.3 \%)$, who met the inclusion criteria, were included in the final analysis. The remaining 27 patients were excluded because they had incomplete data documented in their case files, or were lost to follow-up immediately before or after enrollment on ART. The case files of all the 310 patients were reviewed. The patients were comprised of 138 (44.5\%) males and 172 (55.5\%) females with a median age of 3 (range: $1-15$ ) years, a median weight of $10.4(7.1-15.1) \mathrm{kg}$, and a median height of 93.5 (74.0-110.0) $\mathrm{cm}$. The nutritional statuses of the subjects were normal (178; $57.4 \%)$ or moderately $(39 ; 12.6 \%)$ or severely $(93 ; 30.0 \%)$ malnourished. HIV infection was contracted either from motherto-child transmission $(182 ; 58.8 \%)$ or blood transfusion $(10$; $3.2 \%)$. HIV contraction was, however, unknown in $31(10.0 \%)$ cases and not documented in 87 (28.1\%) cases.

\section{Prescribed ART regimen}

A total of 306 patients $(98.7 \%)$ were enrolled on firstline ART, comprising AZT-3TC-NVP (279; 91.2\%) and
AZT-3TC-EFV (27; 8.8\%). Four (1.3\%) patients were enrolled on a second-line treatment (AZT-3TC-ABC$\mathrm{LPV} / \mathrm{r})$. The first-line ARTs were changed for 66 (21.6\%) patients after initial enrollment. Nearly all the patients $(64 / 66$; 97\%) who switched their ART regimen did so after 1 year of commencing the first-line treatment. Poor adherence and therapeutic failure $(60 / 66 ; 90.9 \%)$, therapeutic failure only ( $4 ; 6.1 \%)$, and adverse drug reaction $(2 ; 3.0 \%)$ were the reasons for changing ARV treatments. The adverse reactions were mainly NVP-induced skin rashes and AZT-induced anemia. None of the adverse reactions were preventable and unrelated to drug-drug interactions. ABC-3TC-LPV/r (20/66; 30.3\%), AZT-3TC-ABC-LPV/r (16/66; 24.2\%), AZT-3TC-ABC-ddI-LPV/r (10/66; 15.2\%), ABC-3TCNVP $(8 / 66 ; 12.1 \%)$, AZT-ABC-LPV/r (6/66; 9.1\%), and AZT-3TC-LPV/r (6/66; 9.1\%) were the types of second-line regimen prescribed. All the ARV drugs were prescribed at standard doses recommended by the $\mathrm{WHO},{ }^{1}$ irrespective of presence or absence of potential drug-drug interactions.

\section{Co-medications for HIV-infected children on ARV drugs}

A wide range of medications were co-prescribed for the patients while on ART regimens. The drugs were used to treat comorbid conditions, opportunistic infections, or concurrent infections. Tuberculosis $(35 ; 11.3 \%)$ was the most common opportunistic infection treated in the patients. It was treated with a combination of rifampicin-isoniazid-pyrazinamide for an average of 6 months either before or during ARV treatment. Presumptively diagnosed malaria (208; 67.1\%), pneumonia $(70 ; 22.6 \%)$, and sepsis $(4 ; 1.3 \%)$ were the concomitant infections frequently treated in the patients.

\section{Identified potential interactions between co-prescribed and ARV drugs}

Table 2 shows the pattern of ARV drug combinations and the co-prescribed drugs with potential for CSDIs in HIV-infected children. The first-line regimens, AZT-3TC-NVP (309; $67.2 \%)$ and AZT-3TC-EFV (65; 14.1\%), were frequently associated with CSDIs, followed by a second-line regimen, ABC-3TC-NVP (30; 6.5\%).

The prevalence and nature of interactions between the co-prescribed and ARV drugs are presented in Table 3. A total of 596 CSDIs were identified in $208(67.1 \%)$ patients. The majority of the interactions $(578 ; 97.2 \%)$ were moderately significant, followed by contraindicated interactions: NVP and rifampicin $(8 ; 1.3 \%)$, EFV and artemisinin/amodiaquine (5; $0.8 \%)$, and NVP and ketoconazole ( $4 ; 0.7 \%)$. Excluding the 
Table 2 Pattern of ARV drug combinations and the co-prescribed drugs with potential for clinically significant drug interactions in HIV-infected children

\begin{tabular}{|c|c|}
\hline \multirow[t]{2}{*}{ ARV and co-prescribed drugs pair } & \multirow{2}{*}{$\begin{array}{l}\text { Number of } \\
\text { prescriptions } \\
\mathbf{N}(\%)\end{array}$} \\
\hline & \\
\hline \multicolumn{2}{|l|}{ AZT-3TC-NVP+ } \\
\hline Artemisinin-based combination therapy & $162(35.3)$ \\
\hline Fluconazole & $55(12.0)$ \\
\hline Prednisolone & $26(5.7)$ \\
\hline Ibuprofen & $25(5.5)$ \\
\hline Clarithromycin & $14(3.1)$ \\
\hline Frusemide & $13(2.8)$ \\
\hline Rifampicin & $8(1.7)$ \\
\hline Ketoconazole & $4(0.9)$ \\
\hline Sulfadoxime/pyrimethamine & $2(0.4)$ \\
\hline \multicolumn{2}{|l|}{ AZT-3TC-EFV ${ }^{+}$} \\
\hline Rifampicin & $27(5.9)$ \\
\hline Artemisinin-based combination therapy & $18(3.9)$ \\
\hline Loratadine & $13(2.8)$ \\
\hline Clarithromycin & $5(1.1)$ \\
\hline Sulfadoxime/pyrimethamine & $2(0.4)$ \\
\hline \multicolumn{2}{|l|}{$A B C-3 T C-N V P^{+}$} \\
\hline Artemisinin-based combination therapy & $8(1.7)$ \\
\hline Metronidazole & $6(1.3)$ \\
\hline Prednisolone & $5(1.1)$ \\
\hline Clarithromycin & $5(1.1)$ \\
\hline Fluconazole & $3(0.7)$ \\
\hline Frusemide & $2(0.4)$ \\
\hline Sulfadoxime/pyrimethamine & $\mathrm{I}(0.2)$ \\
\hline \multicolumn{2}{|l|}{$A B C-3 T C-E F V^{+}$} \\
\hline Metronidazole & $5(1.1)$ \\
\hline Loratadine & $2(0.4)$ \\
\hline Sulfadoxime/pyrimethamine & I $(0.2)$ \\
\hline \multicolumn{2}{|l|}{ AZT-3TC-LPV/r ${ }^{+}$} \\
\hline Artemether/lumefantrine & $6(1.3)$ \\
\hline Proguanil & I $(0.2)$ \\
\hline Ibuprofen & I $(0.2)$ \\
\hline Loratadine & $\mathrm{I}(0.2)$ \\
\hline Furosemide & $\mathrm{I}(0.2)$ \\
\hline Prednisolone & I $(0.2)$ \\
\hline Sulfadoxime/pyrimethamine & $\mathrm{I}(0.2)$ \\
\hline \multicolumn{2}{|l|}{ AZT-3TC-didanosine-LPV/ $/ \mathrm{r}^{+}$} \\
\hline Artemether/lumefantrine & $9(2.0)$ \\
\hline Sulfadoxime/pyrimethamine & $2(0.4)$ \\
\hline Proguanil & I $(0.2)$ \\
\hline Ibuprofen & $\mathrm{I}(0.2)$ \\
\hline Loratadine & $\mathrm{I}(0.2)$ \\
\hline Frusemide & $\mathrm{I}(0.2)$ \\
\hline Prednisolone & $\mathrm{I}(0.2)$ \\
\hline Proguanil & $\mathrm{I}(0.2)$ \\
\hline \multicolumn{2}{|l|}{$A B C-3 T C-L P V / r^{+}$} \\
\hline Artemether/amodiaquine & $4(0.9)$ \\
\hline Metronidazole & $2(0.4)$ \\
\hline Proguanil & I $(0.2)$ \\
\hline Loratadine & $\mathrm{I}(0.2)$ \\
\hline Furosemide & $\mathrm{I}(0.2)$ \\
\hline Prednisolone & $\mathrm{I}(0.2)$ \\
\hline
\end{tabular}

Table 2 (Continued)

\begin{tabular}{ll}
\hline ARV and co-prescribed drugs pair & $\begin{array}{l}\text { Number of } \\
\text { prescriptions }\end{array}$ \\
\cline { 2 - 2 } & $\mathbf{N}(\%)$ \\
\hline ABC-3TC-AZT-LPV/ $\mathrm{r}^{+}$ & \\
Artemether/amodiaquine & $3(0.7)$ \\
Metronidazole & $2(0.4)$ \\
Proguanil & $\mathrm{I}(0.2)$ \\
Loratadine & $\mathrm{I}(0.2)$ \\
Frusemide & $\mathrm{I}(0.2)$ \\
Prednisolone & $\mathrm{I}(0.2)$ \\
Total & $460(100 \%)$ \\
\hline
\end{tabular}

Note: Indicates that the ART was prescribed along with the other drugs such as fluconazole, prednisolone, etc.

Abbreviations: $3 T C$, lamivudine; $A B C$, abacavir; $A R V$, antiretroviral; $A Z T$, zidovudine; EFV, efavirenz; LPV/r, lopinavir/ritonavir; NVP, nevirapine.

Table 3 Prevalence and nature of the potential clinically significant drug interactions in HIV-infected children on antiretroviral (ARV) therapy

\begin{tabular}{|c|c|c|}
\hline $\begin{array}{l}\text { ARV and co-prescribed } \\
\text { drug interaction }\end{array}$ & $\begin{array}{l}\text { Frequency of } \\
\text { occurrence } \\
\mathrm{n}(\%)\end{array}$ & $\begin{array}{l}\text { Rating of } \\
\text { the clinically } \\
\text { significant drug } \\
\text { interaction }^{\mathrm{a}}\end{array}$ \\
\hline $\begin{array}{l}\text { Nevirapine + artemether/ } \\
\text { lumefantrine }\end{array}$ & $170(28.5)$ & C \\
\hline Nevirapine + fluconazole & $58(9.7)$ & C \\
\hline Zidovudine + fluconazole & $55(9.2)$ & C \\
\hline Zidovudine + rifampicin & $35(5.9)$ & $\mathrm{C}$ \\
\hline Nevirapine + prednisolone & $31(5.2)$ & C \\
\hline Zidovudine + ibuprofen & $27(4.5)$ & $\mathrm{C}$ \\
\hline Efavirenz + rifampicin & $27(4.5)$ & $\mathrm{C}$ \\
\hline Zidovudine + clarithromycin & $24(4.0)$ & C \\
\hline Nevirapine + clarithromycin & $19(3.2)$ & C \\
\hline Lamivudine + frusemide & $19(3.2)$ & C \\
\hline Nevirapine + furosemide & $15(2.5)$ & C \\
\hline Abacavir + metronidazole & $15(2.5)$ & $\mathrm{C}$ \\
\hline $\begin{array}{l}\text { Lopinavir/ritonavir + artemisinin- } \\
\text { based combination therapy }\end{array}$ & $15(2.5)$ & C \\
\hline Efavirenz + loratadine & $15(2.5)$ & C \\
\hline $\begin{array}{l}\text { Efavirenz }+ \text { artemisinin-based } \\
\text { combination therapy }\end{array}$ & $13(2.2)$ & C \\
\hline Nevirapine + rifampicin & $8(1.3)$ & $x$ \\
\hline $\begin{array}{l}\text { Lamivudine + sulfadoxine/ } \\
\text { pyrimethamine }\end{array}$ & $8(1.3)$ & C \\
\hline $\begin{array}{l}\text { Lopinavir/ritonavir + artemisinin/ } \\
\text { amodiaquine }\end{array}$ & $7(1.2)$ & C \\
\hline $\begin{array}{l}\text { Efavirenz + artemisinin/ } \\
\text { amodiaquine }\end{array}$ & $5(0.8)$ & $x$ \\
\hline Efavirenz + clarithromycin & $5(0.8)$ & $\mathrm{C}$ \\
\hline Nevirapine + ketoconazole & $4(0.7)$ & $x$ \\
\hline Lopinavir/ritonavir + proguanil & $4(0.7)$ & C \\
\hline $\begin{array}{l}\text { Lopinavir/ritonavir (solution) + } \\
\text { metronidazole }\end{array}$ & $4(0.7)$ & $\mathrm{C}$ \\
\hline Lopinavir/ritonavir + loratadine & $4(0.7)$ & C \\
\hline Lopinavir/ritonavir + frusemide & $4(0.7)$ & $\mathrm{C}$ \\
\hline Lopinavir/ritonavir + prednisolone & $4(0.7)$ & $\mathrm{C}$ \\
\hline $\begin{array}{l}\text { Total potential drug-drug } \\
\text { interactions identified }\end{array}$ & $596(100 \%)$ & \\
\hline
\end{tabular}

Notes: ${ }^{a} \mathrm{C}=$ moderate/monitor therapy; $\mathrm{X}=$ contraindicated/avoid combination. ${ }^{27}$ 
210 CSDIs due to artemisinin-based combination therapy (ACT) in 150 patients, the prevalence of CSDIs reduced from $67.1 \%$ to $18.7 \%$ in 58 patients.

We considered 70 potential interactions might have occurred in 35 patients resulting in decreased plasma concentration of ARV drugs. Such interactions might have occurred between NVP and rifampicin (8; 1.3\%), EFV and rifampicin $(27 ; 4.5 \%)$, and AZT and rifampicin $(35 ; 5.9 \%)$. Similarly, the interactions between NVP and ACT $(210 ; 35.2 \%)$ and between AZT and rifampicin $(35 ; 5.9 \%)$ could potentially decrease the plasma concentration of ARV drugs. This is in contrast, however, to the interactions between NVP and fluconazole (58; 9.7\%), AZT and fluconazole (55; 9.2\%), and NVP and ketoconazole ( $4 ; 0.7 \%)$, which could potentially increase the plasma concentration of ARV drugs.

The effects of the potential ARV-co-prescribed drug interactions, as well as the alternative drugs to use or the necessary ways to manage the patients for the interactions, are summarized in Table 4.

In Table 5, comparing NRTIs, patients receiving AZT were significantly more likely to be at risk of CSDIs than those on $3 \mathrm{TC}$ or $\mathrm{ABC}(P=0.001)$. Although there was no statistically significant difference in the risk for CSDIs between NVP and EFV ( $P=0.723)$, the large difference in the number of patients on these drugs (287 versus 27 patients, respectively) would make it difficult to draw a firm conclusion on the risk of CSDIs with non-NRTIs. There was a significant difference in the clinically significant interactions associated with the three classes of ARV drugs $(P<0.001)$.

Multivariate logistic regression (Table 6) revealed that the risk for CSDIs was not significantly associated with age (odds ratio [OR] 1.07 [0.92-1.23]; $P=0.392$ ), sex (OR 0.89 [0.33-2.38]; $P=0.783$ ), and moderate (OR 0.75 [0.19-3.07]; $P=0.632$ ) or severe (OR 1.17 [0.38-3.65]; $P=0.755$ ) malnourished state of the children.

\section{Discussion}

Drug-drug interactions are often serious complications of multiple drug therapies and account for 3\%-5\% in-patient medication errors in the United States. ${ }^{31}$ ARV drugs are among the most therapeutically risky drugs for CSDIs. ${ }^{8,19}$ A prevalence of $20 \%-50 \%$ has been reported among cohorts of adult HIV patients in the Netherlands, ${ }^{18}$ Kenya,${ }^{8}$ the United Kingdom, ${ }^{21}$ Switzerland, ${ }^{20}$ and New York state, USA. ${ }^{419}$ In the present study, the prevalence of CSDI was $67.1 \%$, which is slightly higher than the values reported in other studies involving adult patients. ${ }^{8,18-21}$ Differences in the sources of information about CSDIs may have accounted for the variations in the prevalence. Previous studies evaluating interactions between non-ARV drugs have reported discrepancies in the interactions identified by Micromedex ${ }^{\circledR}$ and Lexicomp ${ }^{\circledR}$ databases $^{27}$ or Drug Interaction Facts and Micromedex ${ }^{\circledR}$ databases. ${ }^{32}$ In addition, concurrent malaria and tuberculosis in the HIVinfected children has necessitated concomitant treatment with ACT and rifampicin-based antituberculosis therapy, and to a great extent, made CSDIs inevitable. Therefore, these classes of drugs have significantly contributed to the high prevalence observed in this study.

ACT was prescribed for over half of the patients and accounted for $40 \%$ of the CSDIs. Excluding this class of drug, the prevalence of CSDIs reduced from $67.1 \%$ to $18.7 \%$ in 58 patients. This suggests that the concurrent diseases in HIV-infected children, as well as their drug utilization pattern, vary from one country to another and may significantly contribute to the varying prevalence of CSDIs. Since ACT remains the first-line antimalarial drug recommended for use in Nigeria, ${ }^{33}$ its use for children on ART should be strictly based on laboratory evidence of malaria parasites in blood microscopy. This will, at least, reduce the exposure to ACTs caused by presumptive malaria treatment as noted in the present study. Efforts should also be intensified at preventing malaria in HIV/AIDS-infected children. This measure would include the use of insecticide-treated nets ${ }^{34}$ and/or prophylactic antimalarials, such as mefloquine and atovaquone/proguanil. ${ }^{35}$ Both mefloquine and atovaquone/ proguanil are known to lack clinically significant potential interactions with other ARV drugs, except LPV/r. ${ }^{36}$

A pharmacokinetic study demonstrating two- to three-fold increase in the plasma levels of lumefantrine and decrease in the plasma level of artemether, following coadministration of artemether/lumefantrine and LPV/r in HIV-uninfected adults, has highlighted the need for formal safety analysis of the concomitant therapy. ${ }^{37}$ Another pharmacokinetics study involving HIV-infected patients without malaria demonstrated a significantly increased lumefantrine exposure but no increased toxicity when artemether/lumefantrine was coadministered with NVP. ${ }^{38}$ Unfortunately, there has been no case report indicating the significance of the interactions between ACTs and ARV drugs in clinical practice. Data are also lacking on the effects of ACT, used concomitantly with ARV drugs, on malaria parasite clearance in HIV-infected patients. Intensive monitoring of patients for possible adverse drug interaction should be instituted during treatment with ACTs. This can be achieved by regular follow-up visits of the patients and a thorough clinical examination during and after treatment with ACTs. 
Table 4 Consequences of the antiretroviral (ARV) drug-co-prescribed drug interactions in HIV-infected children and the alternative drugs to use

\begin{tabular}{|c|c|c|}
\hline ARV and co-prescribed drug interaction & Potential clinical effects of the interaction & Alternative drug and/or remark \\
\hline Nevirapine + artemether/lumefantrine & $\begin{array}{l}\text { Decreased extent and rate of absorption } \\
\text { of nevirapine and artemether/lumefantrine. }{ }^{28} \\
\text { Potentially increased treatment failure. } .^{28}\end{array}$ & $\begin{array}{l}\text { Quinine, but may require clinical and } \\
\text { laboratory monitoring of the patient. }{ }^{25}\end{array}$ \\
\hline Nevirapine + fluconazole & $\begin{array}{l}\text { Increased rate and extent of absorption of nevirapine. }{ }^{28} \\
\text { Decreased half-life of nevirapine, resulting in } \\
\text { increased effects. }{ }^{28} \\
\text { Potentially increased nevirapine effects. }{ }^{28}\end{array}$ & $\begin{array}{l}\text { Dosage adjustment of nevirapine or } \\
\text { fluconazole is unnecessary; clinical and } \\
\text { laboratory monitoring of the patient is } \\
\text { required. }\end{array}$ \\
\hline Zidovudine + fluconazole & $\begin{array}{l}\text { Zidovudine half-life is increased, resulting in } \\
\text { increased effects. }{ }^{28}\end{array}$ & Ketoconazole. ${ }^{25}$ \\
\hline Zidovudine + rifampicin & Decreased extent of absorption of zidovudine. ${ }^{26}$ & Rifabutin. $^{28}$ \\
\hline Nevirapine + prednisolone & Pyrexia and vomiting. ${ }^{29}$ & $\begin{array}{l}\text { Dosage adjustment of nevirapine or } \\
\text { prednisolone is unnecessary; clinical } \\
\text { and laboratory monitoring of the } \\
\text { patient is required. }{ }^{30}\end{array}$ \\
\hline Zidovudine + ibuprofen & Altered bleeding time reported in a patient. ${ }^{30}$ & Paracetamol or tramadol..$^{25}$ \\
\hline Efavirenz + rifampicin & $\begin{array}{l}\text { Decreased extent and rate of absorption of efavirenz. }{ }^{28} \\
\text { Decreased efavirenz effects. }{ }^{28}\end{array}$ & Rifabutin. $^{25}$ \\
\hline Zidovudine + clarithromycin & $\begin{array}{l}\text { Decreased rate and extent of absorption of zidovudine. }{ }^{25} \\
\text { Decreased plasma level of zidovudine. }{ }^{25}\end{array}$ & Azithromycin. ${ }^{25}$ \\
\hline Nevirapine + clarithromycin & $\begin{array}{l}\text { Decreased rate and extent of absorption of nevirapine. }{ }^{28} \\
\text { Increased blood level of clarithromycin. }{ }^{28}\end{array}$ & Azithromycin. ${ }^{25}$ \\
\hline Lamivudine + frusemide & $\begin{array}{l}\text { Frusemide is a potential substrate and inhibitor } \\
\text { of the renal transporters involved in lamivudine } \\
\text { elimination. }{ }^{25}\end{array}$ & $\begin{array}{l}\text { Dosage adjustment of lamivudine or } \\
\text { frusemide is unnecessary in patients } \\
\text { with normal renal function, but clinical } \\
\text { monitoring may be required. } .^{28}\end{array}$ \\
\hline Nevirapine + frusemide & $\begin{array}{l}\text { Nevirapine may potentially interfere } \\
\text { with the enzymes involved in the renal } \\
\text { elimination of frusemide. } .^{25}\end{array}$ & $\begin{array}{l}\text { Dosage adjustment of nevirapine or } \\
\text { frusemide is unnecessary in patients } \\
\text { with normal renal function, but clinical } \\
\text { monitoring may be required. } .^{28}\end{array}$ \\
\hline Abacavir + metronidazole & Plasma level of abacavir may be increased. ${ }^{25}$ & $\begin{array}{l}\text { Dosage adjustment of abacavir or } \\
\text { metronidazole is unnecessary. Clinical } \\
\text { and laboratory monitoring of the } \\
\text { patient may be required. }{ }^{25}\end{array}$ \\
\hline $\begin{array}{l}\text { Lopinavir/ritonavir }+ \text { artemisinin-based } \\
\text { combination therapy }\end{array}$ & $\begin{array}{l}\text { Ritonavir may increase the plasma levels } \\
\text { of artemisinins. }{ }^{25}\end{array}$ & $\begin{array}{l}\text { Dosage adjustment of lopinavir/ } \\
\text { ritonavir or artemisinins is unnecessary. } \\
\text { Clinical and laboratory monitoring of } \\
\text { the patient may be required. }{ }^{25}\end{array}$ \\
\hline Efavirenz + loratadine & $\begin{array}{l}\text { Efavirenz may increase the conversion } \\
\text { of loratadine to the active metabolite. }{ }^{25}\end{array}$ & $\begin{array}{l}\text { Cetirizine, chlorphenamine, and } \\
\text { promethazine. }{ }^{25} \\
\text { Fexofenadine. } .^{28}\end{array}$ \\
\hline $\begin{array}{l}\text { Efavirenz + artemisinin-based } \\
\text { combination therapy }\end{array}$ & $\begin{array}{l}\text { Decreased artemether, dihydroartemisinin, } \\
\text { and lumefantrine exposures. }{ }^{25}\end{array}$ & $\begin{array}{l}\text { Quinine, but its exposure could be } \\
\text { decreased. }{ }^{25} \\
\text { Dosage adjustment of quinine or } \\
\text { efavirenz is unnecessary. Clinical and } \\
\text { laboratory monitoring of the patient } \\
\text { may be required. } .^{25}\end{array}$ \\
\hline Nevirapine + rifampicin & $\begin{array}{l}\text { Decreased rate and extent of absorption } \\
\text { of nevirapine. }{ }^{28} \\
\text { Decreased half-life of nevirapine. }{ }^{28} \\
\text { Potentially decreased nevirapine effects. } .^{28}\end{array}$ & Rifabutin. $^{28}$ \\
\hline $\begin{array}{l}\text { Lamivudine }+ \text { sulfadoxine/ } \\
\text { pyrimethamine }\end{array}$ & $\begin{array}{l}\text { Potentially decreased lamivudine renal } \\
\text { elimination as in vitro data suggest that } \\
\text { pyrimethamine inhibits the renal transporters } \\
\text { involved in lamivudine elimination. }{ }^{25}\end{array}$ & $\begin{array}{l}\text { Proguanil. }{ }^{25} \\
\text { Dosage adjustment of sulfadoxine/ } \\
\text { Pyrimethamine is unnecessary in } \\
\text { patients with normal renal function, } \\
\text { but clinical monitoring of the patient is } \\
\text { required. }{ }^{25}\end{array}$ \\
\hline
\end{tabular}


Table 4 (Continued)

\begin{tabular}{|c|c|c|}
\hline ARV and co-prescribed drug interaction & Potential clinical effects of the interaction & Alternative drug and/or remark \\
\hline $\begin{array}{l}\text { Lopinavir/ritonavir + artemisinin/ } \\
\text { amodiaquine }\end{array}$ & $\begin{array}{l}\text { Ritonavir may increase plasma levels of artemisinins. }{ }^{25} \\
\text { Lopinavir/ritonavir could potentially increase } \\
\text { amodiaquine exposure. }{ }^{25}\end{array}$ & $\begin{array}{l}\text { Dosage adjustment of either drugs is } \\
\text { unnecessary. } \\
\text { Close monitoring for artemisinin } \\
\text { toxicity and amodiaquine-related } \\
\text { adverse effects are required. }{ }^{25}\end{array}$ \\
\hline Efavirenz + artemisinin/amodiaquine & $\begin{array}{l}\text { Decreased artemether and dihydroartemisinin } \\
\text { exposures. }{ }^{25} \\
\text { Increased amodiaquine exposures. }{ }^{25}\end{array}$ & $\begin{array}{l}\text { Quinine, but its exposure could be } \\
\text { decreased. }{ }^{25} \\
\text { Dosage adjustment of quinine or } \\
\text { efavirenz is unnecessary. Clinical and } \\
\text { laboratory monitoring of the patient } \\
\text { may be required. }{ }^{25}\end{array}$ \\
\hline Efavirenz + clarithromycin & $\begin{array}{l}\text { Decreased clarithromycin exposure and effects. }{ }^{25,28} \\
\text { Increased absorption rate of efavirenz. }{ }^{25,28}\end{array}$ & Azithromycin. ${ }^{25,28}$ \\
\hline Nevirapine + ketoconazole & $\begin{array}{l}\text { Decreased rate and extent of absorption } \\
\text { of ketoconazole. }{ }^{28} \\
\text { Potentially decreased ketoconazole effects } \\
\text { and increased nevirapine effect. } .^{28}\end{array}$ & Efavirenz with fluconazole. ${ }^{25}$ \\
\hline Lopinavir/ritonavir + proguanil & $\begin{array}{l}\text { Decreases the extent of absorption of proguanil. }{ }^{28} \\
\text { Potentially compromises antimalarial activity } \\
\text { of proguanil. }{ }^{28}\end{array}$ & Pyrimethamine. $^{25}$ \\
\hline $\begin{array}{l}\text { Lopinavir/ritonavir (solution) + } \\
\text { metronidazole }\end{array}$ & $\begin{array}{l}\text { Disulfiram reaction (hypotension, headache, } \\
\text { nausea, vomiting) due to the alcohol content } \\
\text { of the lopinavir/ritonavir solution. }{ }^{28}\end{array}$ & Lopinavir/ritonavir capsule. ${ }^{28}$ \\
\hline Lopinavir/ritonavir + loratadine & $\begin{array}{l}\text { May increase loratadine plasma levels, } \\
\text { resulting in increased loratadine effects. }{ }^{25}\end{array}$ & $\begin{array}{l}\text { Cetirizine or chlorphenamine. }{ }^{25} \\
\text { Fexofenadine. }{ }^{28}\end{array}$ \\
\hline Lopinavir/ritonavir + frusemide & $\begin{array}{l}\text { Lopinavir/ritonavir may potentially interfere } \\
\text { with the enzymes involved in the renal } \\
\text { elimination of frusemide. }{ }^{25}\end{array}$ & $\begin{array}{l}\text { Dosage adjustment of lopinavir/ } \\
\text { ritonavir or frusemide is unnecessary in } \\
\text { patients with normal renal function but } \\
\text { clinical monitoring may be required. }{ }^{25}\end{array}$ \\
\hline Lopinavir/ritonavir + prednisolone & $\begin{array}{l}\text { Increases the extent of absorption of prednisolone. }{ }^{28} \\
\text { Possibly increased prednisolone effects. }{ }^{28}\end{array}$ & $\begin{array}{l}\text { Dose adjustment of lopinavir/ritonavir } \\
\text { or prednisolone unnecessary. }{ }^{28}\end{array}$ \\
\hline
\end{tabular}

Other drugs, including fluconazole $(9.7 \%)$, prednisolone $(5.2 \%)$, and clarithromycin (3.2\%), were implicated in the drug interactions and accounted for the broad range of CSDIs observed. This is comparable to the pattern of CSDIs reported in a similar study involving adult HIV patients in Kenya, ${ }^{8}$ but is in contrast to the findings in adult HIV patients in the United Kingdom, where antidepressants, antibiotics, statins, and recreational drugs were the major suspects for CSDIs. ${ }^{21}$

We identified the potential interactions between ARV drugs and fluconazole, prednisolone, or clarithromycin, namely, between NVP and fluconazole, AZT and fluconazole, LPV/r and prednisolone, NVP and prednisolone, AZT and clarithromycin, NVP and clarithromycin, and EFV and clarithromycin. Fluconazole coadministration has the potential to increase the exposure of $\mathrm{NVP}^{39}$ or decrease the exposure of AZT; ${ }^{40}$ however, the authors ${ }^{40}$ noted that the inhibitory effect of fluconazole on AZT was too small to effect a clinically relevant interaction. NVP has the potential to decrease the exposure of prednisolone; ${ }^{29}$ in contrast, NVP can increase the exposure of LPV $/ \mathrm{r}^{41}$ Other studies have also indicated that clarithromycin increases the exposure of $\mathrm{EFV}^{42}$ but decreases the exposures of NVP and AZT. ${ }^{43}$

Theoretically, all the interactions could result in suboptimal treatment, therapeutic failure, or resistance development. Since the interactions in the present study were moderately significant and required therapy monitoring or adjusting, alternative drugs such as azithromycin could have been used in place of clarithromycin in order to avoid the potential interactions. Presently, there are no alternative drugs to replace fluconazole and prednisolone; therefore, concomitant use of these drugs with the ARV drugs that have potential for interactions requires further evaluation.

Most of the CSDIs identified in this study were moderately significant and necessitated dosage adjustment; however, the Liverpool HIV Pharmacology Group website does not provide clinical relevance or detailed strategies for managing the interactions. This may necessitate clinicians prescribing the ARV and co-prescribed drugs to avoid all drug combinations identified as interacting, when indeed the interactions are 
Table 5 Risk of clinically significant drug interactions by individual ARV drug

\begin{tabular}{|c|c|c|c|}
\hline \multirow[t]{2}{*}{ ARV drug } & \multirow{2}{*}{$\begin{array}{l}\text { Total } \\
\text { number of } \\
\text { patients }\end{array}$} & $\begin{array}{l}\text { Clinically significant } \\
\text { drug interactions } \\
\end{array}$ & \multirow[t]{2}{*}{$P$-value } \\
\hline & & $\mathbf{N}(\%)^{\mathbf{a}}$ & \\
\hline \multicolumn{4}{|l|}{ NRTIs } \\
\hline Lamivudine & 310 & $27(8.7)$ & 0.001 \\
\hline Zidovudine & 310 & I4I (45.5) & \\
\hline Abacavir & 66 & I5 (22.7) & \\
\hline \multicolumn{4}{|l|}{ Non-NRTIs } \\
\hline Nevirapine & 287 & $305(106)$ & 0.723 \\
\hline Efavirenz & 27 & $66(244)$ & \\
\hline \multicolumn{4}{|l|}{ Pls } \\
\hline $\begin{array}{l}\text { Lopinavir/ } \\
\text { ritonavir }\end{array}$ & 62 & $42(67.7)$ & \\
\hline
\end{tabular}

Notes: There was a statistically significant difference in the clinically significant interactions associated with the three classes of ARV drugs $(P<0.00 \mathrm{I})$. ${ }^{\text {aB Based }}$ on the number of clinically significant drug interactions relative to the number of patients affected. One or more patients had potential for more than one clinically significant drug interaction.

Abbreviations: ARV, antiretroviral; NRTIs, nucleoside reverse transcriptase inhibitors; Pls, protease inhibitors.

clinically insignificant. Such practice may unnecessarily avert useful therapy options for patients and prevent optimal treatment approaches. Previous studies have documented that many interactions rated moderately significant by Micromedex and Lexicomp databases were found to be clinically insignificant by doctors and pharmacists. ${ }^{27,44}$ Clinicians should, therefore, have a good understanding of the opportunistic infections and comorbid conditions associated with HIV infection, and of the necessity to treat patients with a specific drug combination while monitoring for adverse drug interactions.

Some potential CSDIs (NVP and artemether/lumefantrine, EFV and ACT, NVP and rifampicin, EFV and artemisinin/

Table 6 Multivariate logistic regression of risk for clinically significant drug interactions

\begin{tabular}{|c|c|c|c|c|}
\hline \multirow[t]{2}{*}{ Variable } & \multicolumn{2}{|c|}{$\begin{array}{l}\text { Clinically significant } \\
\text { drug interaction }\end{array}$} & \multirow[t]{2}{*}{$\begin{array}{l}\text { Odds ratio } \\
(95 \% \mathrm{Cl})\end{array}$} & \multirow[t]{2}{*}{$P$-value } \\
\hline & No & Yes & & \\
\hline Sample size, n (\%) & $102(26.5)$ & $208(73.5)$ & - & - \\
\hline \multicolumn{5}{|l|}{ Sex } \\
\hline Male, n (\%) & 45 (I4.5) & $93(30.0)$ & & \\
\hline Female, n (\%) & $57(18.4)$ & 115 (37.1) & $0.83(0.33-2.38)$ & 0.783 \\
\hline $\begin{array}{l}\text { Age (years), } \\
\text { mean (SD) }\end{array}$ & $4.34(3.24)$ & $3.62(3.25)$ & $1.07(0.92-1.23)$ & 0.392 \\
\hline \multicolumn{5}{|l|}{ Nutritional status } \\
\hline Normal, n (\%) & $56(18.1)$ & $122(39.3)$ & & \\
\hline $\begin{array}{l}\text { Moderate } \\
\text { malnutrition, } \\
\mathrm{n}(\%)\end{array}$ & $19(6.1)$ & $20(6.5)$ & $0.73(0.19-3.07)$ & 0.632 \\
\hline $\begin{array}{l}\text { Severe } \\
\text { malnutrition, } \\
\mathrm{n}(\%)\end{array}$ & $27(8.7)$ & $66(21.3)$ & I. $12(0.38-3.65)$ & 0.755 \\
\hline
\end{tabular}

Abbreviations: $\mathrm{Cl}$, confidence interval; $\mathrm{SD}$, standard deviation. amodiaquine, and NVP and ketoconazole) were rated either as contraindicated or moderately significant interactions. Although it is important to avoid all contraindicated drug interactions, we felt the drugs were prescribed according to the best practice of the clinicians after making a riskversus-benefit assessment of the situation. In addition, the clinicians may have rated the interactions clinically insignificant or moderately significant in the context of patient care data. Previous studies comparing drug-drug interactions in patients on cardiovascular drugs have reported that proprietary drug-drug interaction databases rated drug interaction higher in severity than did pharmacists and clinicians involved in the management of the patients. ${ }^{27,44}$

Although many of the previous studies utilized the Liverpool HIV Pharmacology Group drug interaction website, ${ }^{8}$ others utilized the Micromedex database, ${ }^{27}$ summary of product characteristics, ${ }^{4}$ or the United States Department of Health and Human Services Guidelines for the Use of Antiretroviral Agents (DHHS guidelines), ${ }^{7}$ we utilized the Liverpool HIV Pharmacology Group database because it is specifically designed for ARV drug interactions, widely used in clinical practice, and requires no subscription fee.

The first-line (AZT-3TC-NVP) and second-line (ABC-3TC-NVP) ART regimens were frequently associated with CSDIs in this study. The use of these regimens with the suspected co-prescribed drugs would require frequent follow-up visits of the patients with regular monitoring for adverse drug interactions. The few CSDIs associated with AZT in this study may suggest an emtricitabine-based regimen as an alternative. Emtricitabine has been authorized for pediatric use in the United States and in the European Union since 2003. ${ }^{45}$ Its effectiveness and safety as part of the first-line ART regimen has been reported in children; in addition, it does not interact with any of the cytochrome P450 enzymes. ${ }^{45}$

There were a number of limitations to our study. We specifically assessed the potential for clinically significant drug interactions and did not evaluate adverse clinical outcomes arising from these interactions. The incomplete documentation of the viral loads and liver biochemistry at baseline and follow-up made it difficult to assess the impact of adverse drug interactions. We also did not evaluate the relationship between the risk for CSDIs and response to therapy. We probably underestimated or overestimated the prevalence of CSDIs with ARV drugs due to lack of information about self-medicated drugs such as antimalarials, home remedies, and traditional herbal medicines. Accurate determination of the true prevalence of CSDIs 
would, therefore, require a detailed medication history of the patients. We also excluded the potential drug interactions between the non-HIV drugs or between ARV drugs, and did not know if the patients were receiving treatment elsewhere other than the HIV clinic. Overall, our findings appear to have overestimated the true prevalence of potentially significant drug interactions in this cohort of patients, due to frequent prescription of ACTs.

The list of interactions involving ARV drugs is extensive and constantly expanding. Therapeutic drug monitoring is necessary to minimize the risk of drug interaction, but lack of facilities would make this approach a non-feasible strategy for managing CSDIs in Nigeria. A complete drug history review and better medication recording, development of a national treatment guideline that would integrate HIV management with other diseases, establishment of a regional network for pediatric pharmacovigilance, access to online databases for drug interactions with ARV drugs, regular training of health care workers on rational prescribing, knowledge of metabolism of the major drug classes, review of the current ART regimen in Nigeria, and familiarization with common interactions involving risk on a country-specific basis are some of the practical steps that could be instituted to reduce the risk of adverse outcomes from CSDIs.

\section{Conclusion}

A considerable proportion of children who received ART at the APIN clinic LUTH, Nigeria were at risk of CSDIs with a potential to cause subtherapeutic levels of ARV drugs in some patients as well as sub- or supratherapeutic levels of concomitant drugs. Although ACT used for malaria accounted for a significant proportion of the CSDIs, rifampicin used for tuberculosis was the most frequently involved in contraindicated interaction. Large prospective cohort studies are required to confirm that our findings are generalizable to other pediatric HIV treatment centers in Africa. Increasing the availability of ARV drugs in Nigeria would require strategies to be developed in order to avert important CSDIs, to identify early markers of toxicity, and to manage unavoidable interactions so as to reduce the risk of harm of the ARV drugs.

\section{Acknowledgment}

Authors are grateful to medical records staff at LUTH for assisting with the retrieval of patient case files.

\section{Disclosure}

The authors report no conflicts of interest in this work.

\section{References}

1. Antiretroviral Therapy of HIV Infection in Infants and Children: Towards Universal Access. Geneva: World Health Organization; 2006. Available from: http://www.who.int/hiv/pub/guidelines/paediatric020907.pdf. Accessed October 22, 2011.

2. Jordan R, Gold L, Cummins C, Hyde C. Systematic review of metaanalysis of evidence for increasing numbers of drugs in antiretroviral combination therapy. BMJ. 2002;324:757.

3. Pirmohamed M. Drug-drug interactions and adverse drug reactions: separating the wheat from the chaff. Wien Klin Wochenschr. 2010;122: $62-64$.

4. Miller CD, El-Kholi R, Faragon JJ, Lodise TP. Prevalence and risk factors for clinically significant drug interactions with antiretroviral therapy. Pharmacotherapy. 2007;27:1379-1386.

5. Baxter K. Stockley's Drug Interactions. 9th ed. London: Pharmaceutical Press; 2010

6. Tatro DS. Drug Interaction Facts. Facts and Comparisons. St Louis, MO: St Louis Press; 2008.

7. Yiu P, Nguyen NN, Holodniy M. Clinically significant drug interactions in younger and older human immunodeficiency viruspositive patients receiving antiretroviral therapy. Pharmacotherapy. 2011;31:480-489.

8. Kigen G, Kimaiyo S, Nyandiko W, et al; USAID-Academic Model for Prevention Treatment of HIV/AIDS. Prevalence of potential drug-drug interactions involving antiretroviral drugs in a large Kenyan cohort. PLoS One. 2010;6:e16800.

9. Bruce RD, Altice FC. Three case reports of a clinical pharmacokinetic interaction with buprenorphine and atazanavir plus ritonavir. AIDS. 2006;20;783-784.

10. McCance-Katz EF, Moody DE, Morse GD, et al. Interaction between buprenorphine and atazanavir or atazanavir/ritonavir. Drug Alcohol Depend. 2007;91:269-278.

11. Altice FC, Friedland GH, Cooney EL. Nevirapine induced opiate withdrawal among injection drug users with HIV infection receiving methadone. AIDS. 1999;13:957-962.

12. German P, Greenhouse B, Coates C, et al. Hepatotoxicity due to a drug interaction between amodiaquine plus artesunate and efavirenz. Clin Infect Dis. 2007;44:889-891.

13. Uriel A, Lewthwaite P. Malaria therapy in HIV: drug interactions between nevirapine and quinine. Int J STD AIDS. 2011;22:768.

14. Frohoff C, Moodley M, Fairlie L, et al. Antiretroviral therapy outcomes in HIV-infected children after adjusting protease inhibitor dosing during tuberculosis treatment. PLoS One. 2011;6.

15. Zhang C, McIlleron H, Ren Y, et al. Population pharmacokinetics of lopinavir and ritonavir in combination with rifampicin-based antitubercular treatment in HIV-infected children. Antivir Ther. 2012;17:25-33.

16. Greenfield RA, Rivera DM, Frye RE, et al. Pediatric HIV infection treatment and management [webpage on the Internet]. Medscape [updated September 3, 2013]. Available from: http://emedicine.medscape.com/ article/965086-treatment. Accessed November 4, 2011.

17. Young B. Review: mixing new cocktails: drug interactions in antiretroviral regimens. AIDS Patient Care STDS. 2005;19:286-297.

18. de Maat MM, de Boer A, Koks CH, et al. Evaluation of clinical pharmacist interventions on drug interactions in outpatient pharmaceutical HIV-care. J Clin Pharm Ther. 2004;29:121-130.

19. Shah S, McGowan J, Opulski B, Lieblein A, Saperstein A. Identification of Drug Interactions Involving Antiretroviral Therapy (ART) in New York City HIV Specialty Clinics 2007. Available from: http://www. hiv-druginteractions.org/data/NewsItem/45_CROI\%202007_1.pdf. Accessed December 12, 2012

20. Marzolini C, Elzi L, Gibbons S, et al; Swiss HIV Cohort Study. Prevalence of comedications and impact of potential drug-drug interactions in the Swiss HIV Cohort Study. Antivir Ther. 2010;15: 413-423.

21. Evans-Jones JG, Cottle LE, Back DJ, et al. Recognition of risk for clinically significant drug interactions among HIV-infected patients receiving antiretroviral therapy. Clin Infect Dis. 2010;50:1419-1421. 
22. Brown BJ, Oladokun RE, Odaibo GN, Olaleye DO, Osinusi K, Kanki P. Clinical and immunological profile of pediatric HIV infection in Ibadan, Nigeria. J Int Assoc Physicians AIDS Care (Chic). 2011;10:49-53.

23. WHO Multicentre Growth Reference Study Group. WHO Child Growth Standards based on length/height, weight and age. Acta Paediatr Suppl. 2006;450:76-85

24. National Guidelines for Paediatric HIV and AIDS Treatment and Care. Federal Ministry OF Health Nigeria; 2007. Available from: http://www. who.int/hiv/amds/Nigeria_paediatric_2007.pdf. Accessed November 30 2011.

25. Liverpool HIV Pharmacology Group (LHPG). Available from: http:// www.hiv-druginteractions.org/main.aspx?PageId=7. Accessed December 1, 2011.

26. Guyatt GH, Oxman AD, Vist GE, et al; GRADE Working Group. GRADE: an emerging consensus on rating quality of evidence and strength of recommendations. BMJ. 2008;336:924-926.

27. Armahizer M, Kane-Gill SL, Smithburger PL, Anthes AM, Seybert AL. Comparing drug-drug interaction severity for clinician opinion to proprietary databases. Adv Pharmacoepidemiol Drug Saf. 2012;1:115.

28. Database of antiretroviral drug interactions [database on the Internet]. San Francisco, CA: University of California San Francisco. Available from: http://hivinsite.ucsf.edu/InSite?page=ar-00-02. Accessed February 25, 2013

29. Review: prednisone and nevirapine [webpage on the Internet]. eHealthMe; 2013. Available from: http://www.ehealthme.com/druginteractions/prednisone-and-nevirapine. Accessed June 2, 2013.

30. Pieper B, Smitherman HC Jr. Altered bleeding time associated with ibuprofen and zidovudine use. Nurse Pract. 1998;23:74-75, 80, 83.

31. Leape LL, Bates DW, Cullen DJ, et al. Systems analysis of adverse drug events. ADE Prevention Study Group. JAMA. 1995;274:35-43.

32. Wong CM, Ko Y, Chan A. Clinically significant drug-drug interactions between oral anticancer agents and nonanticancer agents: profiling and comparison of two drug compendia. Ann Pharmacother. 2008;42: 1737-1748.

33. Federal Republic of Nigeria. National Antimalarial Treatment Policy. Abuja: Federal Ministry of Health, National Malaria and Vector Control Division; 2005. Available from: http://apps.who.int/medicinedocs/ documents/s18401en/s18401en.pdf. Accessed October 12, 2012.

34. Edelu BO, Ikefuna AN, Emodi JI, Adimora GN. Awareness and use of insecticide-treated bed nets among children attending outpatient clinic at UNTH, Enugu - the need for an effective mobilization process. Afr Health Sci. 2010;10:117-119.
35. Infection and travel in patients with HIV disease: malaria prophylaxis [webpage on the Internet]. San Francisco, CA: University of California San Francisco. Available from: http://hivinsite.ucsf.edu/InSite?page=kb03-01-09\#S3.5X. Accessed February 25, 2013.

36. Khoo S, Back D, Winstanley P. The potential for interactions between antimalarial and antiretroviral drugs. AIDS. 2005;19:995-1005.

37. German P, Parikh S, Lawrence J, et al. Lopinavir/ritonavir affects pharmacokinetic exposure of artemether/lumefantrine in HIVuninfected healthy volunteers. J Acquir Immune Defic Syndr. 2009;51: 424-429.

38. Kredo T, Mauff K, Van der Walt JS, et al. Interaction between artemether-lumefantrine and nevirapine-based antiretroviral therapy in HIV-1-infected patients. Antimicrob Agents Chemother. 2011;55: 5616-5623.

39. Wakeham K, Parkes-Ratanshi R, Watson V, Ggayi AB, Khoo S, Lalloo DG. Co-administration of fluconazole increases nevirapine concentrations in HIV-infected Ugandans. J Antimicrob Chemother. 2010;65:316-319.

40. Brockmeyer NH, Tillmann I, Mertins L, Barthel B, Goos M. Pharmacokinetic interaction of fluconazole and zidovudine in HIVpositive patients. Eur J Med Res. 1997;2:377-383.

41. Violari A, Lindsey JC, Hughes MD, et al. Nevirapine versus ritonavirboosted lopinavir for HIV-infected children. N Engl J Med. 2012;366: 2380-2389.

42. Robinson P, Gigliotti M, Lamson M, Azzam S, Macgregor T. Effect of reverse transcriptase inhibitor, nevirapine, on the steady-state pharmacokinetics of clarithromycin in HIV-positive patients [abstract \#374] 6th Conference on Retroviruses and Opportunistic Infections; January 30 February 2, 1999; Chicago, IL. Available from: http://retroconference. org/1999/abstracts/374.htm. Accessed January 7, 2013.

43. Polis MA, Piscitelli SC, Vogel S, et al. Clarithromycin lowers plasma zidovudine levels in persons with human immunodeficiency virus infection. Antimicrob Agents Chemother. 1997;41:1709-1714.

44. Smithburger PL, Kane-Gill SL, Benedict NJ, Falcione BA, Seybert AL. Grading the severity of drug-drug interactions in the intensive care unit: a comparison between clinician assessment and proprietary database severity rankings. Ann Pharmacother. 2010;44:1718-1724.

45. FTC (emtricitabine, Emtriva) [webpage on the Internet]. London: NAM Publications. Available from: http://www.aidsmap.com/resources/ treatmentsdirectory/drugs/FTC-emtricitabine-iEmtrivai/page/1731063/. Accessed February 24, 2013.
HIV/AIDS - Research and Palliative Care

\section{Publish your work in this journal}

HIV/AIDS - Research and Palliative Care is an international, peerreviewed open-access journal focusing on advances in research in HIV, its clinical progression and management options including antivira treatment, palliative care and public healthcare policies to control viral spread. The journal welcomes original research, basic science,

\section{Dovepress}

clinical \& epidemiological studies, reviews \& evaluations, expert opinion \& commentary, case reports \& extended reports. The manuscript management system is completely online and includes a very quick and fair peer-review system. Visit http://www.dovepress.com/ testimonials.php to read real quotes from published authors. 